\title{
SOSIALISASI EKONOMI SYARIAH PADA SISWA SMA NEGERI 1 MASBAGIK KECAMATAN MASBAGIK LOMBOK TIMUR
}

\author{
Jalaludin ${ }^{1}$, Satarudin ${ }^{2}$, Himawan Sutanto ${ }^{3}$ \\ Jurusan Ilmu Ekonomi dan Ekonomi Pembangunan Universitas Mataram \\ din.jalani@gmail.com
}

\begin{abstract}
ABSTRAK
Pengembangan Ekonomi yang berbasis syariah/ islam di Indonesia tak terkecuali di NTB didasarkan atas kenyataan bahwa Indonesia merupakan negara dengan penduduk muslim terbesar di dunia. Dengan penduduk yang mayoritas muslim, maka harapan untuk pengelolaan ekonomi yang sejalan dengan prinsip syariah berdasarkan Al-Quran dan Al-Hadits, menjadi suatu keniscayaan. Sejalan dengan kondisi dan harapan di atas, maka konsep dan aktivitas ekonomi yang berlandaskan syari'at Islam perlu di desiminasikan dan disosialisasikan kepada semua lapisan masyarakat termasuk para siswa SMA agar memiliki refrensi dan preverensi serta pemahaman sebelum mereka terjun ke dunia bisnis atau melanjukan kuliah nanti. Sosialisasi ekonomi syariah pada Sekolah Menengah Atas Negeri (SMAN 1) Masbagik ini bertujuan untuk 1.) memberikan pengetahuan dan pemahaman (transfer of knowledge) kepada para siswa SMA tentang konsep atau sistem ekonomi yang berbasis syariah/ islam 2). Memberikan pengetahuan dan pemahaman (transfer of knowledge) kepada siswa mengenai keunggulan sistem ekonomi syari'ah/ islam dibandingkan dengan ekonomi konvensional. Metode yang digunakan adalah metode ceramah dilengkapi dengan tanya jawab atau diskusi. Dari sosialisasi yang dilakukan setidaknya ada dua kesimpulan yaitu 1). Para siswa SMA Negeri 1 Masbagik masih sangat awam dengan ekonomi syari'ah atau ekonomi yang berbasis syari'ah bahkan mendengarkannya saja baru pertama kali yaitu pada saat sosialisasi dilaksanakan. Hal ini mejadi justifikasi kuat betapa kegiatan sosialisasi ini menjadi penting, dan bahkan dilanjutkan untuk khalayak yang lebih luas. 2). Secara tekhnis operasional, kegiatan sosialisasi cukup berhasil dan berjalan lancar tampa hambatan yang berarti. Demikian pula dalam penyampaian materi nyaris tampa hambatan dan berlangsung komonikatif dan interaktif. Hal ini dimungkinkan karena tim pengabdian FEB UNRAM telah berkoordinasi dengan pihak sekolah seminggu sebelum acara dilaksanakan.
\end{abstract}

Kata Kunci : Sosialisasi, Ekonomi Syariah, Pengelolaan Ekonomi 


\begin{abstract}
Economic development based on sharia/Islam in Indonesia is no exception in NTB based on the fact that Indonesia is a country with the largest Muslim population in the world. With a Muslim majority population, the hope for economic management that is in line with sharia principles based on the Al-Quran and AlHadith, becomes a necessity. In line with the conditions and expectations above, economic concepts and activities based on Islamic law need to be disseminated and socialized to all levels of society including high school students in order to have references and references and understanding before they enter the business world or continue their studies later. The socialization of sharia economics at the State Senior High School (SMAN 1) Masbagik aims to 1.) provide knowledge and understanding (transfer of knowledge) to high school students about the concept or economic system based on sharia/islam 2). Provide knowledge and understanding (transfer of knowledge) to students regarding the advantages of the sharia/Islamic economic system compared to conventional economics. The method used is the lecture method equipped with question and answer or discussion. From the socialization carried out there are at least two conclusions that can be drawn, namely 1). The students of SMA Negeri 1 Masbagik are still very unfamiliar with sharia economics or sharia-based economics, even listening to it for the first time, namely when the socialization is carried out. This is a strong justification for how important this socialization activity is, and even continues for a wider audience. 2). Technically operational, the socialization activities were quite successful and ran smoothly without any significant obstacles. Likewise, the delivery of material is almost unimpeded and communicative and interactive takes place. This was possible because the FEB UNRAM service team had coordinated with the school a week before the event was held.
\end{abstract}

Keywords: Socialization, Islamic Economics, Economic Management

\title{
PENDAHULUAN
}

Pembangunan ekonomi masyarakat/ umat sudah menjadi suatu keharusan yang tidak bisa ditawar- tawar lagi. Hal ini sejalan dengan adanya tuntutan masyarakat/umat akan perlunya revitalisasi kommitmen pembangunan ekonomi nasional seperti yang dicita- citakan oleh para pendiri republik ini sebagaimana yang tertuang dalam pasal 27 dan pasal 33 UUD 1945.

Di sisi lain, adanya transformasi informasi dan pemikiran msyarakat/ umat yang semakin kritis, menjadikan masyrakat semakin sadar akan berbagai aspek penting dalam kehidupan perekonomian nasional yang hingga kini belum 
terwujud kedalam format seperti yang dicita- citakan. Hal ini ditandai dengan masih adanya berbagai bentuk kesenjangan yang terjadi di masyarakat baik secara sektoral, antar kelompok jenis usaha maupun bidang usaha.

Paradigma baru sistem ekonomi dewasa ini sering menjadi pembicaraan atau diskursus oleh berbagai kalangan terlebih oleh para ekonom, baik dari akademisi maupun praktisi. Munculnya suatu konsep yang dianggap baru belum tentu begitu saja dapat diterima oleh masyarakat, karena belum adanya pemahaman terhadap konsep yang ditawarkan tersebut. Salah satu konsep yang banyak dibicarakan saat ini adalah konsep mengenai perekonomian yang berbasis syariah/ islam, dimana konsep ini menerapkan prinsip- prinsip syariah islam ke dalam transaksi ekonomi umat.

Munculnya konsep atau ajaran islam dalam dunia usaha modern memang merupakan fenomena baru, walaupun sesungguhnya model transaksi atau bermuamalah secara islam merupakan sesuatu yang melekat (built-up) pada agama islam itu sendiri. Bila pemikiran dunia barat didasarkan pada kepuasan dengan parameter tertentu, maka pemikiran islam didasarkan pada pengaplikasian syariah berdasarkan Al-Qura'an dan Al-hadits pada ruang lingkup ekonomi (Marthon, 2004).

Sementara itu upaya untuk mendorong pengembangan Ekonomi yang berbasis syariah/ islam di Indonesia didasarkan atas kenyataan bahwa Indonesia merupakan negara dengan penduduk muslim terbesar di dunia. Dengan penduduk yang mayoritas muslim sudah barang tentu masyarakat/ umat islam Indonesia mengharapkan suatu sistem ekonomi yang berdasarkan syariah untuk mengakomodasikan kebutuhan mereka akan aktifitas ekonomi yang sejalan dengan prinsip syariah berdasarkan Al-Quran dan Al-Hadits. Demikian pula halnya dengan masyarakat/ umat Islam di Nusa Tenggara Barat (NTB) terutama di pulau lombok yang dikenal sebagai daerah seribu mesjid, dimana mayoritas penduduknya $(95,66 \%)$ adalah muslim yang sangat religius, maka aktivitas ekonomi yang berdasarkan syari'ah menjadi semakin penting bagi pemberdayaan ekonomi umat. 
Kegiatan ekonomi yang halal, pelarangan segala bentuk riba, penerapan pola hidup sederhana, pelaksanaan zakat-infaq-shadaqah, berkeadilan, dan nilai-nilai universal lainnya, merupakan state of the art dari Ekonomi Islam (Attariqi, 2004). Kesesuaian Sistem tersebut dengan fitrah manusia, ditegakkannya kejujuran dan keadilan, kebebasan berekonomi yang terkendali menjadi ciri penting Sistem Ekonomi Islam. Kebebasan memiliki unsur produksi dalam menjalankan roda perekonomian tanpa merugikan kepentingan kolektif. Kepentingan individu dibuka lebar, tidak adanya batasan pendapatan bagi seseorang mendorong manusia untuk aktif berkarya dengan segala potensi yang dimilikinya, kecenderungan manusia untuk terus menerus memenuhi kebutuhan pribadinya yang tak terbatas dikendalikan dengan adanya kewajiban setiap indivudu terhadap masyarakatnya. Keseimbangan antara kepentingan individu dan kolektif inilah menjadi pendorong bagi bergeraknya roda perekonomian tanpa merusak tatanan sosial yang berkeadilan dan beradab.

Disisi lain kegagalan sistem ekonomi kapitalis dan sosialis untuk mensejahterakan umat manusia secara berkeadilan, telah mendorong munculnya wacana dan diskusi di kalangan akademisi di berbagai kampus di berbagai negara tak terkecuali di Indonesia tentang sistem ekonomi alternative yang dapat mensejahterakan umat manusia secara berkeadilan dan berkesinambungan. Diskursus- diskursus yang terjadi sampai pada suatu kesimpulan bahwa kegagalan kedua sitem ekonomi konvensional baik kapitalis maupun sosialis terletak pada terpisahnya urusan ekonomi dan agama pada kedua system ekonomi tersebut, yang kemudian lebih dikenal dengan sebutan ekonomi sekuler (Afzalurrahman, 2015).

Namun pada saat yang sama para pakar ekonomi belum banyak yang mendalami kaitan antara agama dengan ekonomi dalam dunia praksis sehingga agama seolah dianggap hanyalah mengatur urusan ritual ibadah semata. Pada hal agama Islam adalah agama yang konfrehensip, tidak hanya mengatur masalah ritual ibadah, tapi juga sosial muamalah.

Lebih dari itu, Islam mengatur cara hidup yang seimbang dan koheren, dirancang untuk kebahagiaan (falah) manusia dengan cara menciptakan keharmonisan antara kebutuhan moral dan material manusia dan aktualisasi 
keadilan sosio ekonomi serta persaudaraan dalam masyarakat manusia (Qardhawi Yusuf, 2005). Himbauan akan kebahagiaan yang berorientasikan keseimbangan dan keadilan tersebut diulang- ulang dari menara mesjid sebanyak lima kali sehari semalam. Namun hingga saat ini masih terdapat anggapan bahwa Islam menghambat pembangunan. Beberapa kalangan mencurigai Islam sebagai factor penghambat pembangunan (an obstacle to economic growth). Pandangan ini berasal dari para pemikir barat, namun tidak sedikit intelektual muslim juga meyakininya.

Kesimpulan yang agak tergesa-gesa ini ditimbulkan oleh kesalah pahaman terhadap Islam. Seolah-olah Islam merupakan agama yang berkaitan dengan masalah ritual bukan sebagai suatu sistem yang komprehensip yang mencakup seluruh aspek kehidupan termasuk masalah pembangunan ekonomi dan industri perbankan yang merupakan motor penggerak roda perekonomian. Padahal Islam sebagai agama yang lengkap tidak hanya memuat mengenai aspek ritual ibadah semata tetapi mencakup seluruh aspek kehidupan manusia. Islam mengatur hubungan antara manusia dengan Allah (hablumminallah), hubungan manusia dengan manusia dan alam sekitar (hablumminannas). Bahkan lebih dari itu islam tidak hanya memberikan penerangan kepada manusia untuk kemaslahatan hidup di dunia tetapi juga untuk kehidupan di akhirat nanti.

Sejalan dengan kondisi dan harapan di atas, maka konsep dan aktivitas ekonomi yang berlandaskan syari'at Islam perlu didesiminasikan dan disosialisasikan kepada semua lapisan masyarakat termasuk para siswa SMA agar memiliki refrensi dan pereverensi serta pemahaman sebelum mereka terjun ke dunia bisnis atau melanjukan kuliah pada saat mereka menamatkan sekolahnya nanti. Adapun tujuan dari pengabdian kepada masyarakat atau sosialisasi ini adalah :

1. Memberikan pengetahuan (transfer of knowledge) kepada para siswa SMA tentang ekonomi yang berbasis syariah/ islam terutama yang terkait dengan konsep dan prinsip operasionalnya. 
2. Memberikan pengetahuan (transfer of knowledge) kepada siswa mengenai keunggulan ekonomi syari'ah/ islam dibandingkan dengan ekonomi konvensional.

Sedangkan manfaat dari kegiatan pengabdian kepada masyarakat ini adalah:

1. Para siswa memiliki pengetahuan awal tentang system ekonomi syariah/ sistem ekonomi yang berbasis syari'ah terutama yang terkait dengan konsep dan prinsip operasionalnya.

2. Para siswa memiliki Pengetahuan tentang keunggulan sistem ekonomi syariah/ system ekonomi yang berbasis syari'ah dibandingkan dengan sistem ekonomi konvensional.

3. Dengan adanya pengetahuan tentang ekonomi yang berbasis syari'ah/islam, diharapkan semakin banyak siswa yang melanjutkan kuliah ke Fakultas Ekonomi dengan mengambil Jurusan/ Program studi Ilmu Ekonomi Syari'ah/ Ilmu Ekonomi Islam.

\section{METODE KEGIATAN}

Sasaran dari kegiatan penyuluhan ini adalah para siswa kelas tiga (III) jurusan Ilmu Pengetahuan Sosial (IPS) dan para guru yang mengajar ekonomi di Sekolah Menengah Atas (SMA) Negeri 1 Masbagik kecamatan Masbagik kabupaten Lombok Timur. Penyampaian materi penyuluhan dilakukan dengan menggunakan metode ceramah yaitu salah satu metodologi pembelajaran dimana penyampaian informasi pembelajaran kepada peserta didik dilakukan dengan cara lisan. Metode ini sangat cocok diterapkan di tempat dengan jumlah peserta yang cukup besar. Metode ceramah bisa aplikasikan di dalam kelas atau di dalam gedung dengan jumlah murid yang cukup banyak. Dengan menggunakan metode ini, seorang pengajar akan lebih mudah menjelaskan materi-materinya (Ferdiansyah, 2017).

Untuk mengukur keberhasilan dari pelaksanaan pengabdian pada masyarakat ini, dilakukan dengan melihat tingkat kehadiran para peserta yang menjadi target atau sasaran dari pengabdian atau penyuluhan serta keaktifan dalam melakukan diskusi/ tanya jawab terhadap materi yang disampaikan. Bila 
peserta yang hadir mencapai sekitar $75 \%$ atau lebih dari target, dan materi penyuluhan telah dapat diterima dengan baik yang dicerminkan dalam aktifitas diskusi atau sesi Tanya jawab, maka kegiatan ini dapat dikatakan berhasil.

Sementara itu untuk memastikan kegiatan penyuluhan ini berjalan dengan baik dan lancar, maka sebelumnya tim pengabdian pada masyarakat berkoordinasi dengan lembaga dan stakeholder terkait, terutama BP2EB Fakultas Ekonomi dan Bisnis Universitas Mataram dan pihak sekolah SMAN 1 Masbagik kecamatan Masbagik Lombok Timur yang menjadi tempat atau lokasi kegiatan sosialisasi.

\section{HASIL DAN PEMBAHASAN}

Kegiatan pengabdian masyarakat yang beragendakan "Sosialisasi ekonomi syariah pada siswa Sekolah Menengah Atas (SMA) Negeri 1 Masbagik kecamatan Masbagik kabupaten Lombok Timur" ini dilaksanakan pada hari Sabtu tanggal 03 Agustus tahun 2019, bertempat di gedung Aula yang sekaligus berfungsi sebagai Masjid Sekolah Menengah Atas (SMA) Negeri 1 Masbagik.

Peserta dalam kegiatan sosialisasi ini seperti yang direncakan dalam proposal pengabdian adalah para siswa kelas 3 jurusan Ilmu Pengetahuan Sosial (IPS). Namun dalam pelaksanaannya pimpinan sekolah yang dalam hal ini diwakili oleh Wakil Kepala Sekolah bidang Kesiswaan mengambil kebijakan untuk melibatkan seluruh siswa klas 3 termasuk jurusan IImu Pengetahuan Alam (jurusan IPA). Hal ini didasarkan atas pertimbangan bahwa hal ini penting bagi para siswa, mengingat bukan hanya siswa jurusan IPS saja yang berminat untuk memahami ekonomi islam, tetapi juga jurusan lain, bahkan banyak diantar mereka yang jurusan IPA kitika melanjutkan kuliah memilih untuk menyeberang ke ilmu social termasuk fakultas Ekonomi. Jumlah peserta secara keseluruhan termasuk wakil kepala sekolah dan guru yang mengampu mata pelajaran IImu Ekonomi adalah sebanyak 125 orang.

Kegiatan sosialisasi ini berlangsung selama kurang lebih 2 jam dan sedianya dimulai pada jam 09.30 WITA, namun karena pada saat yang sama masih berlangsung acara/ kegiatan imtaq yang selesai pada pukul 10.00 WITA, maka 
acara baru bisa dimulai pada pukul 10.15 WITA. Karena bertempat di Aula yang sekaligus berfungsi sebagai Mushalla atau masjid sekolah, maka acara sosialisasi ini dilakukan dengan dengan cara duduk atau lesehan. Tidak banyak acara protokuler yang dilakukan dalam sosialisasi ini, prosesi atau susunan acara dilakuakn cukup sederhana, namun tidak mengurangi substansi dari acara sosialisasi.

Acara sosialisasi diawali dengan penjelasan dan pengarahan dari Kepala Sekolah yang dalam hal ini di wakili oleh Wakil Kepala Sekolah bidang Kesiswaan (Drs. Lalu Suryadi). Dalam pengarahannya, Wakil kepala sekolah bidang kesiswaan pada intinya menjelaskan pentingnya materi yang akan disampaikan oleh pemateri nanti, oleh karenanya dimainta kepada para siswa untuk tenang dan mengikuti sosialisasi dengan baik dan penuh perhatian. Untuk memastikan semua itu, kepala sekolah bersama guru pengampu mata pelajaran ekonomi terjun langsung mengikuti sekaligus mengawasi para siswa dalam mengikuti materi yang disampaikan

Acara kemudian dilanjutkan dengan acara inti yaitu penyampaian materi sosialisasi, diserahkan sepenuhnya kepada tim pengabdian masyarakat Fakultas Ekonomi dan Bisnis (FEB) Universitas Mataram. Sebelum menyampaikan materi tim terlebih dahulu memperkenalkan diri dan menjelaskan pentingnya materi yang akan disampaikan. Hal ini dilakukan selain untuk lebih mendekatkan diri dengan para audiensi atau para siswa peserta sosialisasi, juga dimaksudkan untuk membuat suasana lebih cair, namun tetap fokus untuk mengikuti acara sampai akhir. Tidak lupa juga dijelaskan aturan main atau role of the game dari acara dimaksud dimana acara atau penyampaian materi dilakukan dalam dua sesi yaitu; sesi 1 (satu) tim pengabdian menyampaikan materi sampai selesai dan sesi 2 (dua) adalah sesi tanya jawab atau diskusi. Namun diluar itu para peserta diberikan kebebasan untuk bertanya atau interupsi sekira ditengah penyampain materi ada yang kurang dimengerti atau kurang jelas.

Seperti yang telah diuraikan sebelumnya, bahwa pengabdian kepada masyarkat yang beragendakan Sosialisasi Ekonomi Islam/ Syari'ah pada siswa SMA Negeri 1 Masbagik ini dilakukan dengan menggunakan metode ceramah. Materi ceramah atau sosialisasi disampaikan melalui power point. Dipilihnya metode 
Ceramah, karena metode ceramah ini memiliki beberapa kebaikan dan kelebihan dibanding dengan metode lain. Beberapa kebaikan dan keunggulan metode ceramah antara lain (Dodik, 2011):

1. Dapat menampung kelas besar dan tiap siswa mempunyai kesempatan yang sama untuk mendengarkan. Oleh karenanya biaya yang diperlukan lebih murah.

2. Bahan pelajaran dapat diberikan secara urut, ide atau konsep dapat direncanakan dengan baik.

3. Penceramah/ fasilitator dapat menekankan hal-hal yang penting, sehingga waktu dan energi dapat digunakan sehemat mungkin.

4. Materi ceramah/ silabus dapat dilakukan menurut jadwal, karena fasilitator tidak harus menyesuaikan dengan kecepatan belajar siswa.

5. Kekurangan atau tidak adanya buku pelajaran dan alat bantu pelajaran tidak menghambat jalanya pelajaran.

Disamping memiliki kelebihan dan keunggulan, metode ceramah memiliki beberapa kelemahan atau kekurangan. Beberapa kelemahan atau kekurangan dari metode ceramah ini adalah (Dodik, 2011) :

1. Penyampaian materi terkadang terkesan monoton membosankan peserta karena mereka tidak diberi kesempatan untuk menemukan sendiri konsep yang diajarkan.

2. Peserta menjadi pasif hanya aktif membuat catatan saja.

3. Kepadatan konsep-konsep yang diajarkan dapat berakibat peserta tidak mampu menguasai bahan/ materi yang disampaikan.

4. Pengetahuan yang diperoleh melalui ceramah lebih cepat terlupakan.

5. Ceramah menyebabkan sistem belajar siswa menjadi "belajar menghafal" dan tidak mengacu pada timbulnya pengertian.

Untuk meminimalisir kelemahan tersebut, maka fasilitator atau tim pengabdian memberikan kesempatan kepada para siswa untuk berperan aktif dalam acara sosialisasi ini, dimana para siswa boleh melakukan intrupsi atau bertanya saat penyampaian materi sedang berlangsung. Hal ini dimaksudkan agar para peserta yang belum jelas atau kurang mengerti dengan penyampain materi 
oleh pfasilitator atau panyaji bisa melakukan klarifikasi secara langsung, hal ini juga sekaligus dimaksudkan untuk membuat suasana belaiar lebih cair dan hidup sekaligus menghilangkan kejemuan dari peserta. Metode Tanya jawab ini juga diharapkan dapat menggali hal- hal yang sikiranya tidak tercouper atau tidak tersampaikan pada saat ceramah berlangsung, sehingga dengan adanya metode Tanya jawab ini akan dapat memperkaya konsep dan materi yang di bahas.

Diawal presentasi, yaitu sebelum materi inti disampaikan, sebagai kata pembukaan atau sebagai ice breaking kami melontarkan pertanyaan kepada para siswa atau para peserta apakah mereka pernah mendengar tentang ekonomi syari'ah?. Jawaban mereka diluar dugaan mereka kompak menjawab belum pernah, bahkan mendengarnya saja baru sekarang. Hal ini menunjukan betapa ekonomi yang berbasis syariah masih begitu asing di sebagian besar masyarakat kita termasuk para siswa SMA, yang notebandnya mayoritas beragama Islam, jangankan secara konsep akademik, secara istilah saja mereka belum familiar. Hal ini juga membuktikan betapa kemudian kgiatan sosialisasi ini menjadi penting dan bisa dilanjutkan untuk khalayak yang lebih luas.

Antusiasme peserta dalam mengikuti acara ini boleh dikatakan sangat bagus, terlihat dari kehadiran peserta yang tidak ada satupun yang beranjak sejak awal acara sampai acara selesai. Namun disayangkan ditengah antusiasme mereka, banyak yang ingin bertanya tidak terakomodir, karena terbatasnya waktu. Ahirnya kegiatan sosialisasi ini ditutup tepat 10 menit menjelang waktu shalat dhuhur, dan semua peserta termasuk tim pengabdian melaksanakan sholat duhur berjamaah. Sehabis shalat duhur sebelum pulang kami/ tim pengabdian masyarakat diterima di ruang kepala sekolah sembari berdiskusi seputar mata pelajaran ekonomi yang di ajarkan di sekolah SMA1 Masbagik yang ternyata memang belum mengenal mata pelajaran ekonomi syari'ah. Pada intinya kepala sekolah dan guru pengampu mata pelajaran ekonomi yang ikut hadir dalam pertemuan itu menyatakan minat dan ketertarikannya untuk ikut mendesiminasikan mata pelajaran ekonomi syariah di SMA1 Masbagik. Untuk itu guru pengampu mata pelajaran ekonomi akan memperjuangkannya nati melalui perubahan kurikulum. 


\section{Jurnal ABDIMAS INDEPENDEN}

Vol. 2, No. 1, Mei 2021

Akhirnya sebelum kami dari tim pengabdian pulang kembali ke Mataram, guru pengampu mata pelajaran ekonomi meminta file atau power point materi ekonomi syaria'h yang disampaikan dalam sosialisasi tadi, namun karena laptop sudah dimasukkan dalam ransel kami berjanji akan mengirimkan file/ power point dimaksud, melalui email dan itu sudah dipenuhi.

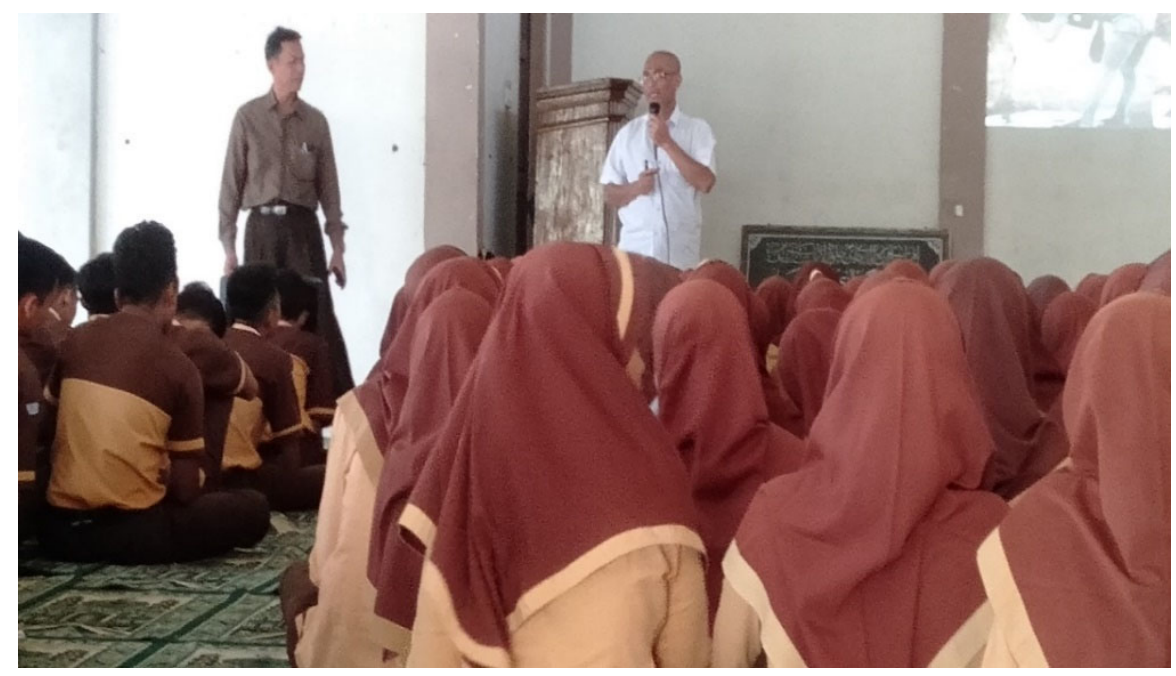

Gambar 1: Kegiatan Pengabdian

\section{KESIMPULAN DAN SARAN}

Berdasarkan latar belakang, tujuan dan manfaat dari pelaksanaan pengabdian ini serta berdasarkan pengamatan dalam pelaksanaanya, maka dapat disimpulkan beberapa hal sebagi berikut :

1. Para siswa SMA Negeri 1 Masbagik masih sangat awam dengan ekonomi syari'ah atau ekonomi yang berbasis syari'ah bahkan mendengarkannya saja baru pertamakali yaitu pada saat sosialisasi dilaksanakan. Hal ini menjadi justifikasi yang kuat betapa kegiatan sosialisasi ini menjadi penting, dan bahkan dilanjutkan untuk khalayak yang lebih luas.

2. Secara tekhnis operasional, kegiatan sosialisasi ini bisa dikatakan berhasil dan berjalan cukup lancar tampa hambatan yang berarti. Demikian pula dalam penyampaian materi nyaris tampa hambatan bahkan cukup komonikatif dan interaktif. Hal ini dimungkinkan karena tim pengabdian 
FEB UNRAM telah berkoordinasi dengan pihak sekolah seminggu sebelum acara dilaksanakan.

\section{UCAPAN TERIMA KASIH}

Ucapan terima kasih disampaikan kepada Lembaga Penelitian dan Pengabdian Masyarakat Universitan Mataram (LPPM UNRAM), Fakultas Ekonomi dan Bisnis Universitas Mataram Cq. BP2EB FEB UNRAM dan kepala sekolah SMAN 1 Masbagik serta jajarannya wabilkhusus guru pengampu mata pelajaran ekonomi atas kerja samanya.

Kami menyadari bahwa tulisan/ artikel pengabdian pada masyarakat ini masih banyak kekurangannya dan jauh dari sempurna oleh karenanya kritik dan saran yang sifatnya membangun selalu kami harapkan. Ahirnya kepada Allah kami serahkan semua kiranya laporan pengabdian pada masyarakat ini bisa bermanfaat terutama bagi fihak- fihak yang berkepentingan.

\section{DAFTAR PUSTAKA}

Afzalurrahman, 2015, Dokterin Ekonomi Islam Jilid 1, edisi revisi PT Dana Bhakti Wakaf Yogyakarta.

Dodik,http://zonainfosemua.blogspot.com/2011/01/pengertian-kelebihan-dan kekurangan.html (diunduh 24 Agustus, 2019)

Husain at-Tariqi, Abdullah Abdul, 2004 , Ekonomi Islam : Prinsip, Dasar dan Tujuan, Magistra Insani Press Yogyakarta. (diunduh tgl 24 Agustus 2019)

IrfanFerdiansyah,2017ttp://irfanferdiansyahdikdas.blogspot.com/2017/01/peng ertian-metode-ceramah.html

Marthon Said Saad, 2014, Ekonomi Islam Di Tengah Krisis Ekonomi Global, Zikrul Hakim Jakarta.

Qardhawi Yusup, 2005, Norma dan Etika Ekonomi Islam, Magistra Insani Press Yogyakarta. 